\title{
Guest Editor's Preface: Dutch-Based Creoles
}

\author{
Gerald Stell \\ F.W.O./V.U.B./University of Pretoria
}

A linguistic outcome of colonial expansion, creole languages have been classified in various terms. Prominent among these are areal terms (for example, Caribbean creoles versus Asian creoles), lexical terms (for example, Spanish-based creoles versus English-based creoles), sociohistorical terms (for example, "plantation" creoles, which emerged in the context of plantations, versus "fort" creoles, which emerged in and around European trading posts; see Bickerton 1988), or structural terms (for example, "radical" creoles, that is, languages that display the maximal range of structural features deemed characteristic of creoles, versus "nonradical" creoles, or "creoloids," that is, languages that display but a limited range of such features; see Bickerton 1977, Trudgill 1983).

The structural classification may have lost some currency, not least on account of disagreements over what structural features categorically distinguish creoles in general (compare Winford 2008, Bakker et al. 2011). The classification in sociohistorical terms may have been superseded by the areal classification, because the geographic label Caribbean may generally be taken to imply a plantation creole, whereas the geographic labels West African or Asian may generally be taken to imply a fort creole. It is, however, lexical properties which are the most widespread criterion for classification, as evidenced in the recently published Survey of Pidgin and Creole Languages (Michaelis et al. 2013), and also in Holm 2000 as well as in a range of edited volumes and monographs devoted to English-, French- or Portuguese-based creoles.

As most Dutch-based creoles are extinct and for a large part poorly documented, it does not come as a surprise that they have never really been treated as an independent topic. However, Dutch-based creoles are regularly mentioned, with varying degree of detail, in general surveys of creole languages, such as Michaelis et al. 2013 and Holm 2000. They are also mentioned in historical accounts of the Dutch language, most recently in De Vries et al. 1993, after being originally introduced in 
depth in van Ginneken 1928. The rationale behind including Dutch-based creoles in general surveys of creole languages and in historical accounts of the Dutch language seems to be comprehensiveness in the former case, and Eurocentric historical reconstruction of the colonial expansion of the Dutch language in the latter.

The rationale behind this present special issue-for a large part devoted to Dutch-based creoles - is different. Despite the small number of Dutch-based creoles, their study seems to have consistently revealed "anomalies," whose elucidation is essential to our understanding of creole genesis and evolution. It therefore seems justified to present, in condensed form, advances made in the reconstruction of the dynamics that gave rise to Dutch-based creoles and to their idiosyncrasies. Also, part of the rationale behind this special issue is to provide historical studies of English-based creoles - which dominate modern creolisticswith a point of comparison within the typological paradigm of Germanic languages.

Dutch is comparable with English not only on account of being a Germanic language; Dutch and English have both functioned as colonial languages for roughly the same period of time. Besides, the ideological contexts of their colonial spread are comparable by virtue of, among other things, having been conducive to similar forms of racial segregation. For example, slave manumission rates, a seemingly potent factor in creolization in the New World, were relatively low in British and Dutch American territories; by contrast, they were relatively high in the Iberian New World, where historical evidence of linguistic creolization has-possibly, as a result-proven inconclusive (Lipski 2008, Lucchesi 2009). The rigid segregation patterns which the British and the Dutch implemented in their colonies gave rise to obvious parallel linguistic developments. For example, radical creoles developed as much in British as in Dutch plantation societies. This, of course, cannot be considered extraordinary since radical creoles also emerged in the French Caribbean (Holm 2000). Yet, specific to British and Dutch colonies is that they saw the emergence of language varieties that have featured at the centre of the discussion on creoloids. However extensively documented these language varieties are, such as, in particular, African American Vernacular English and Cape Dutch/Afrikaans, their respective histories and typological similarities/differences arguably deserve to be compared more systematically, following the attempt by Holm (2004). 
The bulk of creole studies have tended to limit their scope to language varieties that emerged in the sociolinguistic context of the Transatlantic slave trade in general, and of New World plantation societies in particular (see, for example, Bickerton 1984). Since the only uncontroversial similarity between these language varieties seems to be that they emerged in colonial contexts (Mufwene 1999), there is arguably a case for treating creolization in its traditional sense on a par with other language contact phenomena that arose in the colonial world, and that are still observable in the postcolonial world. Such phenomena include borrowing (lexical or structural) from the superstrate into indigenous languages and code switching between the superstrate and indigenous languages.

It is on that ground that this special issue addresses not only Dutchbased creoles, but also colonial and postcolonial language contact phenomena involving Dutch as well as languages not necessarily typologically related to it. In this respect, the contents of this special issue could be said to mirror recent developments in the field of English studies: There has been a call for integrating into the field the study of postcolonial Englishes ("New Englishes," see Kachru 1988), of English-based creole varieties (Bolton 2006), and also of code switching between English and indigenous languages in postcolonial contexts (Mesthrie 2006).

The colonial spread of Dutch took place in two successive stages (Groeneboer 1997). It began, for a large part, in the context of the maritime expansion of the United Provinces from the late 16th century onwards. Yet Dutch did not take hold everywhere the United Provinces acquired a colonial foothold: Portuguese remained the dominant lingua franca in those territories which had been seized from Portugal, such as New Holland (in modern-day northeastern Brazil), or most Asian possessions of the Dutch East Indian Company. Where it did take hold was either settlement colonies, that is, the Cape of Good Hope (in modernday South Africa) and New Netherland (in the modern-day northeastern US), or territories where no other European colonial power had preceded the Dutch, such as the Essequibo and Berbice settlements (in modern-day Guyana). It did also take hold in a colonial territory settled for the most part by Dutch colonists, but which did not fall within Dutch jurisdiction, namely, the Danish West Indies (modern-day US Virgin Islands).

Dutch colonization spawned a range of creoles or creoloids. In structural terms, those Dutch-based creoles that can be described as radical 
comprise Skepi Dutch, Berbice Dutch (once spoken in the Essequibo and Berbice settlements, respectively), and Negerhollands (once spoken in the Danish West Indies), whereas Cape Dutch/Afrikaans, which emerged in the Dutch Cape Colony, has conversely been described as nonradical, or creoloid. Other possible Dutch-based creoloids are Mohawk River Dutch and New Jersey Dutch, once spoken in the New York area, where the Dutch New Netherland settlement had been founded (Holm 2000). In sociohistorical terms, those Dutch-based creoles that fall under the label plantation creole are Skepi Dutch, Berbice Dutch, and Negerhollands. The only Dutch-based creole that has ever been referred to as a fort creole is Cape Dutch/Afrikaans (den Besten 1989).

Outside of Southern Africa, where it dramatically spread in the context of the 19th-century Boer and Coloured migrations, the second stage of the colonial spread of Dutch began in the late 19th-early 20th century, with the Dutch government introducing Dutch as the language of education in its remaining colonies: the Dutch East Indies (modernday Indonesia), Suriname, the Dutch Leeward and Windward Islands. In all of these territories, Dutch had thus far not managed to impose itself as a lingua franca. While Dutch did, as a result of new education policies, manage to establish itself as an L2 in these territories, it is only in Suriname that it acquired the status of a universal lingua franca, if not of a majority L1. Intensive contact between Dutch and Surinamese languages has given rise to widespread patterns of bilingualism-if not trilingualism - among the Surinamese population, resulting in intensive code switching and structural borrowing from Dutch into Surinamese languages (Carlin \& Arends 2002).

Negerhollands is perhaps the best-documented creole among all extinct Dutch-based creoles/creoloids. Unlike most other creoles, it developed as a written medium from the 18th century, and as a result, its early varieties can be reconstructed on the basis of archival materials (Rossem \& van der Voort 1996). Prominent among the as yet unanswered questions regarding the development of Negerhollands is the origin of the rather stark discrepancies between its early varieties, as documented in archival materials, and its more recent varieties, reconstructed based on the recordings of its last known speakers: A comparison between the two suggests, in sharp contrast to established scenarios of creole evolution, that the more recent varieties are more radical or basilectal (that is, more distant from Dutch), while the earlier 
varieties are less radical or basilectal (that is, less distant from Dutch; see Bakker, this issue). Also in sharp contrast to established scenarios of creole evolution, Berbice Dutch displays a mixed lexical base derived from both Dutch and Ijo, whereas the lexical base of other Dutch-based creoles is overwhelmingly Dutch; Berbice Dutch also has Ijo morphology, whereas other Dutch-based creoles-and most creoles for that matter-exhibit little to no morphology (Kouwenberg 2013, Bakker, this issue). Finally, thus far little has been achieved in the way of a historical reconstruction of Skepi Dutch due to limited documentation available on that language (Bakker, this issue).

Afrikaans historical linguistics has brought forth widely different accounts of the emergence of Cape Dutch/Afrikaans (see Roberge 1994 for a comprehensive overview). Eurocentric views postulate that the bulk of the defining features of Cape Dutch/Afrikaans form a continuation of Netherlandic dialects, and that the morphological reduction it displays is owed to the presence of L2 Dutch speakers at the colonial Cape. Substratalist views, such as those spearheaded by den Besten (1989), see instead Khoekhoe languages - and to some extent also Asian languages - as having played an essential role in the development of Cape Dutch/Afrikaans by facilitating the retention of certain Dutch features (for example, SOV with V2, prefixation of past participles) or the development of local features (for example, the brace negation).

In his account, Roberge (1994) casts doubt on the absolute validity of both Eurocentric and substratalist scenarios. Instead he argues for the possibility that some of the defining features of Cape Dutch/Afrikaans may have resulted from the reinterpretation of features found simultaneously in Dutch dialects and other languages spoken at the Cape without necessarily reflecting any of those features directly. In any event, there seems to be an agreement that Cape Dutch/Afrikaans formed a continuum of varieties ranging from basilectal to acrolectal, in which continued albeit occasionally obstructed exposure to Standard Dutch played a stabilizing role, especially during the standardization process that saw the emergence of Standard Afrikaans in the early 20th century.

The contributions to this special issue examine both general and specific structural features of a range of Dutch-based creole languages, as well as the structural impact of Dutch on other languages in colonial/postcolonial settings. Peter Bakker offers a comparative perspective on the emergence of four radical Dutch-based creoles formerly 
spoken in the Caribbean, namely, Berbice Dutch, Skepi Dutch, 18thcentury Negerhollands, and 20th-century Negerhollands. At the core of that comparative perspective is the statistical evaluation of varying degrees of kinship among these creoles, based on a range of lexical and grammatical features. Among his conclusions is that these creoles have developed autonomously from one another, although suggestions are present that Skepi Dutch and Berbice Dutch may have to some extent interacted.

On the basis of a corpus of Negerhollands narratives, Robbert van Sluijs examines in detail one idiosyncratic grammatical feature of Negerhollands, namely, the use of overt pasts where other creoles tend to use zero pasts. After testing the validity of a range of scenarios, he finally reaches the conclusion that the diachronically increasing over-representation of that feature may have been due to language shift affecting Negerhollands in the 20th century rather than to alignment with superstratal grammar. This can provide a more likely explanation for the occurrence of overt pasts in other creoles.

Frans Hinskens focuses on the historical phonological dynamics behind the variable deletion and lenition processes that affected Cape Dutch, whose traces are visible in modern-day Standard Afrikaans. His contribution reviews the various factors conducive to variable deletion and lenition, including language-internal factors and contact-induced factors, such as superstratal influence from Standard Dutch and substratal influence from Khoekhoe languages.

Finally, Robert Borges focuses on structural effects of contemporary contact with Dutch on Surinamese languages. More specifically, he elaborates on the emergence in Sranan Tongo, Ndyuka, and Kwinti (Maroon languages) of nonindigenous constructions modeled after Dutch verb-particle constructions (VPC). Although VPCs have as yet not come to replace their indigenous equivalents, they seem-especially in the case of Sranan Tongo - to have become internalized to some extent.

This special issue comprises articles based on topics discussed at the international workshop Towards a Social Typology of Language Contact and Genesis in the (Post-)Colonial Context: The Example of Overseas Dutch-Based Creoles, held in Brussels on November 23-24, 2012, under a grant awarded by the Centre for Linguistics (CLIN) of the Vrije Universiteit Brussel and the Language in Contact group of the Radboud Universiteit. I am deeply indebted to Wim Vandenbussche (VUB) as 
well as to Pieter Muysken (Radboud), whose role in the organization of this workshop was invaluable. I would also like to extend my gratitude to Paul T. Roberge, Consulting Editor, and the scholars who served as anonymous referees for the articles included in this special issue.

\section{REFERENCES}

Bakker, Peter, Aymeric Daval-Markussen, Mikael Parkvall, \& Ingo Plag. 2011. Creoles are typologically distinct from non-creoles. Journal of Pidgin and Creole Languages 26. 5-42.

Besten, Hans den. 1989. From Khoekhoe foreigner talk via Hottentot Dutch to Afrikaans: The creation of a novel grammar. Wheels within wheels. Papers of the Duisburg Symposium on Pidgin and Creole Languages, ed. by Martin Pütz \& René Dirven, 207-250. Frankfurt am Main: Peter Lang.

Bickerton, Derek. 1977. Pidginisation and creolization: Language acquisition and language universals. Pidgin and creole linguistics, ed. by Albert Valdman, 49-69. Bloomington, IN: Indiana University Press.

Bickerton, Derek. 1984. The language bioprogram hypothesis. The Behavioural and Brain Sciences 7. 173-221.

Bickerton, Derek. 1988. Creole languages and the bioprogram. Linguistics: The Cambridge survey, vol. 2: Linguistic theory: Extensions and implications, ed. by Frederick J. Newmeyer, 268-284. Cambridge: Cambridge University Press.

Bolton, Kingsley. 2006. World Englishes today. Kachru, Kachru \& Nelson 2006, 240-270.

Carlin, Eithne B., \& Jacques Arends. 2002. Atlas of the languages of Suriname. Leiden: KITLV Press.

De Vries, Jan, Roland Willemyns, \& Peter Burger. 1993. Het verhaal van een taal: Negen eeuwen Nederlands. Amsterdam: Prometheus.

Groeneboer, Kees. 1997. Koloniale taalpolitiek in Oost en West. NederlandsIndië, Suriname, Nederlandse Antillen, Aruba. Amsterdam: Amsterdam University Press.

Holm, John. 2000. An introduction to pidgins and creoles. Cambridge: Cambridge University Press.

Holm, John. 2004. Languages in Contact. The partial restructuring of vernaculars. Cambridge: Cambridge University Press.

Kachru, Braj B. 1988. The sacred cows of English. English Today 16.3-8.

Kachru, Braj B., Yamuna Kachru, \& Cecil L. Nelson (eds.). 2006. The handbook of World Englishes. London: Wiley. 
Kouwenberg, Silvia. 2013. The historical context of creole language in Dutch Guiana. Revue Belge de Philologie et d'Histoire 90. 1237-1254.

Lipski, John. 2008. Spanish-based creoles in the Caribbean. Kouwenberg \& Singler 2008, 543-564.

Lucchesi, Dante. 2012. A diferenciação da língua portuguesa no Brasil e o contato entre línguas. Estudos de Lingüística Galega 4. 45-65.

Mesthrie, Rajend. 2006. Contact linguistics and World Englishes. Kachru, Kachru \& Nelson, 273-288.

Michaelis, Susanne M., Maurer, P., \& Martin Haspelmath. 2013. The survey of pidgin and creole languages, vol. I. Oxford: Oxford University Press.

Mufwene, Salikoko. 1998. Creolization is a social, not a structural, process. Paper presented at the International Symposium on Degrees of Restructuring in Creole Languages held in Regensburg, June 24-27, 1998.

Roberge, Paul. 1994. The formation of Afrikaans. SPIL Plus 23. 1-113.

Rossem, Cefas, \& Hein van der Voort. 1996. Di Creol Taal: 250 years of Negerhollands texts. Ann Arbor, MI: University of Michigan Press.

Trudgill, Peter. 1983. Language contact and language change: On the rise of the creoloid. On dialect: Social and geographical perspectives, ed. by Peter Trudgill, 102-107. Oxford: Blackwell.

Van Ginneken, Jacobus. 1928. Handboek der Nederlandsche taal, Deel I. De sociologische structuur der Nederlandsche taal. 's Hertogenbosch: Malmberg.

Winford, Donald. 2008. Atlantic creole syntax. Kouwenberg \& Singler 2008, 19-47.

\author{
F.W.O./V.U.B./University of Pretoria \\ Pleinlaan 2 \\ 1050 Elsene \\ Belgium \\ [gstell@vub.ac.be]
}

